\title{
LOJALNA SURADNJA INSTITUCIJA EUROPSKE UNIJE PRI PROVOĐENJU ČLANKA 7. UGOVORA O EUROPSKOJ UNIJI
}

\author{
Dr. sc. Stjepan Novak*
}

\author{
UDK 341.176(4)EU \\ https://doi.org/10.30925/zpfsr.41.3.8 \\ Ur.: 26. kolovoza 2020. \\ Pr.: 15. listopada 2020. \\ Pregledni rad
}

\begin{abstract}
Sažetak
Cilj je ovoga rada istražiti je li suradnja institucija Unije u vezi s provođenjem $i$ poboljšanjem učinkovitosti članka 7. UEU-a sukladna s načelom lojalne suradnje te može li Sud EU-a, štiteći načelno lojalne suradnje između institucija, posredno ojačati učinkovitost članka 7. UEU-a i zaštititi temeljne vrijednosti iz članka 2. UEU-a. U tu se svrhu u radu, nakon uvodnoga dijela, istražuje kako su institucije Unije pokušale poboljšati učinkovitost članka 7. UEU-a te analizira međusobna suradnja koju su pritom ostvarile. U trećem se dijelu ukazuje na praksu Suda EU-a o pitanju lojalne suradnje institucija Unije te se primjenjuju zaključci koji proizlaze iz nje povezani s institucionalnom suradnjom iz članka 7. UEU-a. Autor zaključuje kako ta suradnja ne odgovara zahtjevu lojalne suradnje iz članka 13. UEU-a, ali i kako bi Sud EU-a, osnažujući obvezu lojalne suradnje institucija Unije, posredno mogao poboljšati učinkovitost članka 7. UEU- $a$.
\end{abstract}

Ključne riječi: članak 7. UEU-a; članak 13. UEU-a, lojalna suradnja institucija Unije; praksa Suda EU-a.

\section{1. $U V O D$}

U rujnu 2012. tadašnji predsjednik Europske komisije Barroso nazvao je članak 7. Ugovora o Europskoj uniji (u daljnjem tekstu: UEU) „nuklearnom opcijom“. Uistinu, članak 7. UEU-a ne samo da propisuje stroge uvjete za njegovo pokretanje, osobito kad je riječ o stavku 2., već propisuje i teške sankcije za državu protiv koje se

* Dr. sc. Stjepan Novak, Ministarstvo unutarnjih poslova Republike Hrvatske; stjepannovak@ hotmail.com. 
pokreće. ${ }^{1}$ Ugled ovoga članka kao neupotrebljivog, ${ }^{2}$ potvrdio se pri njegovoj aktivaciji protiv Poljske i Mađarske. S vremenom se stvori dojam da Unija i nije toliko zabrinuta stanjem u tim državama ili, ako i jest, ne raspolaže odgovarajućim mehanizmom za rješavanje problema destrukcije temeljnih vrijednosti u tim državama. ${ }^{3}$ To, naravno, nije bilo tako, no trebalo je proći puno vremena da pojedine institucije ostvare svoje ovlasti iz članka 7. UEU-a. Tako je Komisija pokrenula, tzv. preventivni mehanizam iz članka 7. stavka 1. UEU-a protiv Poljske u prosincu 2017., dok je Parlament taj isti postupak pokrenuo protiv Mađarske u rujnu 2018. Do danas, osim što su održana tri saslušanja s Poljskom i dva s Mađarskom, ${ }^{4}$ postupak nije daleko odmakao.

$\mathrm{U}$ tom je smislu članak 7. postao neodgovarajući i neučinkoviti alat. ${ }^{5} \mathrm{U}$ teoriji i praksi brojni su prijedlozi kako poboljšati njegovu učinkovitost. ${ }^{6} \mathrm{~S}$ obzirom na to da izmjene UEU-a nije realno očekivati, ${ }^{7}$ veću učinkovitost članka 7. nužno je pokušati postići bez izmjena Ugovora. ${ }^{8}$

1 Dimitry Kochenov, „Busting the Myths Nuclear: A Commentary on Article 7 TEU“, EUI Working Papers, br. 10 (2017): 8, http://dx.doi.org/10.2139/ssrn.2965087; Olivier De Schutter, „Infringement Proceedings as a Tool for the Enforcement of Fundamental Rights in the European Union“, Open Society European Policy Institute, Open Society Foundations (2017): 39, https://www.opensocietyfoundations.org/uploads/f637765b-ee20-4e6e-9cda-b74151f9a369/ infringement-proceedings-as-tool-for-enforcement-of-fundamental-rights-in-eu-20171214. pdf.

2 Jan Werner Müller, Should the EU Protect Democracy and the Rule of Law Inside Member States?, http://www.princeton.edu/ jmueller/ELJ-Democracy\%20Protection-JWMueller-pdf. pdf, 12.

3 Dimitry Kochenov i Petra Bard, „The Last Soldier Standing? Courts vs. Politicians and the Rule of Law Crisis in the New Member States of the EU“, European Yearbook of Constitutional Law 1, (2019): 16, https://papers.ssrn.com/sol3/papers.cfm?abstract_id=3339631.

4 Rezolucija Europskog parlamenta od 16. siječnja 2020. o saslušanjima u tijeku u skladu s člankom 7. stavkom 1. UEU-a u pogledu Poljske i Mađarske (2020/2513(RSP)), pristup 23.11.2020. https://www.europarl.europa.eu/doceo/document/TA-9-2020-0014_HR.html.

5 Bojan Bugarič, „Protecting Democracy and the Rule of Law in the European Union: The Hungarian Challenge“, LEQS Paper 79 (2014): 3, http://dx.doi.org/10.2139/ssrn.2466340; Iris Goldner Lang, „The Rule of Law, the Force of Law and the Power of Money in the EU“, Croatian Yearbook of European Law \& Policy 15, br. 1 (2019): 15; Jasna Šelih, Ian I. Bond, i Carl Dolan, „Can EU funds promote the rule of law in Europe?“, Centre for European Reform (2017): 4, https://www.cer.eu/sites/default/files/pbrief_structural_funds_nov17.pdf; Müller, Should the EU Protect Democracy and the Rule of Law Inside Member States?, 12; Leo L. Hotham, i Lucas Nacif, „Article 7 TEU and the Polish case - a recast“, KSLR EU Law Blog (2018), https://blogs.kcl.ac.uk/kslreuropeanlawblog/?p=1274\#.XxaUNJ4zaUm.

6 Vidi npr. Müller, Should the EU Protect Democracy and the Rule of Law Inside Member States?; Floris de Witte, Less Constraint of Popular Democracy, More Empowerment of Citizens, 2013., https://verfassungsblog.de/less-constraint-of-popular-democracy-more-empowerment-ofcitizens/\#.UX5E80a2iM8; Marco Dani, Opening the enforcement of EU fundamental values to European citizens, 2013., https://verfassungsblog.de/opening-the-enforcement-of-eufundamental-values-to-european-citizens/.

7 Dmitry Kochenov i Laurent Pech, „Upholding the Rule of Law in the EU: On the Commission's 'Pre-Article 7 Procedure' as a Timid Step in the Right Direction“, EUI Working Papers br. 24 (2015): 10, https://cadmus.eui.eu/bitstream/handle/1814/35437/RSCAS_2015_24.pdf. Vidi i Closa, Kochenov, Weiler, Reinforcing Rule of Law Oversight in the European Union, 7.

8 Carlos Closa, Dimitry Kochenov i Joseph H. H. Weiler, „Reinforcing Rule of Law Oversight 
Međutim, prepreka učinkovitosti svih prijedloga i samoga članka 7. UEU-a jest nedostatna institucijska suradnja.

Dani, predstavljajući svoj prijedlog o građanskoj inicijativi kao novom spiritus movens aktivacije članka 7. UEU-a, navodi kako će mobilizacija građana riješiti institucijsku blokadu u kojoj se trenutačno nalaze institucije Unije kad je u pitanju pokretanje tog članka. ${ }^{9}$

Closa, Kochenov i Weiler, kao rješenje problema kršenja temeljnih vrijednosti Unije, a koje bi se temeljilo na postojećim odredbama Ugovora, vide u zajedničkom čitanju članaka 2., 4., stavka 3., 3. stavka 1. i 13. stavka 1. UEU-a. ${ }^{10}$ Time bi na temelju članka 2. UEU-a, nastajale konkretne obveze za države članice u smislu očuvanja tih vrijednosti te bi Unija, pri kršenju te obveze, imala pravni temelj za poduzimanje odgovarajućih mjera prema tim državama članicama. Smatramo da bi u tom kontekstu članak 2. UEU-a trebalo tumačiti u kontekstu članka 13. stavka 2., koji institucijama nameće obvezu lojalne suradnje te djelovanja u granicama ovlasti koje su im dodijeljene u Ugovorima. ${ }^{11}$

Predmet je interesa ovog rada odnos institucija Unije u kontekstu provođenja članka 7. UEU-a s aspekta obveze lojalne suradnje iz članka 13. stavka 2. UEU-a.

Cilj je rada istražiti, koristeći se kazuističkom metodom, je li suradnja institucija Unije u vezi s provođenjem i poboljšanjem učinkovitosti članka 7. UEU-a sukladna s načelom lojalne suradnje te može li Sud EU-a, štiteći načelno lojalne suradnje između institucija, posredno ojačati učinkovitost članka 7. UEU-a i zaštititi temeljne vrijednosti iz članka 2. UEU-a.

\section{SURADNJA INSTITUCIJA PRI PRIMJENI ČLANKA 7. UEU-A}

U Novom okviru EU-a za jačanje vladavine prava $\operatorname{COM(2014)} 158$ final (u daljnjem tekstu: Okvir za jačanje vladavine prava), Komisija je predvidjela tri etape koje bi prethodile pokretanju postupka iz članka 7. UEU-a. U prvoj etapi, Komisija bi trebala prikupiti i pregledati sve relevantne informacije, procijeniti postoje li jasne naznake sustavne prijetnje vladavini prava te objaviti svoju procjenu. U drugoj etapi, Komisija bi trebala izdati ,preporuku o vladavini prava” upućenu određenoj državi članici ako utvrdi postojanje objektivnih dokaza sustavne prijetnje i da nadležna tijela te države članice ne poduzimaju odgovarajuće mjere za njezino uklanjanje. U trećoj bi etapi Komisija trebala pratiti mjere koje je država članica eventualno poduzela sukladno s preporukom te ovisno o tome razmotriti potrebu pokretanja postupka iz

in the European Union“, Robert Schuman Centre for Advanced Studies Research 25, (2014): 8, https://papers.ssrn.com/sol3/papers.cfm?abstract_id=2404260. Vidi i Šelih, Bond, Dolan, Can EU funds promote the rule of law in Europe?, 1.

9 Dani, Opening the enforcement of EU fundamental values to European citizens.

10 Closa, Kochenov, Weiler, Reinforcing Rule of Law Oversight in the European Union, 9.

11 Vidi Christophe Hillion, ,, Overseeing the rule of law in the European Union Legal mandate and means“, Swedish Institute for European Policy Studies, European Policy Analysis (2016): 3, https://www.sieps.se/en/publications/2016/overseeing-the-rule-of-law-in-the-european-unionlegal-mandate-and-means-20161epa/Sieps20161 epa?. 


\section{članka 7. UEU-a. ${ }^{12}$}

Pravna služba Vijeća, 27. travnja 2014. donijela je Mišljenje, prema kojem Okvir za jačanje vladavine prava nije u skladu s načelom dodjeljivanja kojim se uređuju nadležnosti institucija Unije. Ključna je konstatacija Mišljenja da: „u Ugovorima ne postoji pravna osnova za davanje ovlasti institucijama za stvaranje novog mehanizma nadzora poštovanja vladavine prava od strane država članica, kao dodatak onome što je navedeno u članku 7. UEU-a niti za mijenjanje ili dopunjavanje postupka navedenog u tom članku“". ${ }^{13}$

Pitanje koje se ovdje postavlja jest stvara li se novi mehanizam nadzora ili je nadzor koji Okvir za jačanje vladavine prava predviđa razrada već postojećih ovlasti koje Komisija ima upravo na temelju članka 7. UEU-a. ${ }^{14}$ Preventivni se mehanizam pokreće na temelju obrazloženog prijedloga jedne trećine država članica, Europskog parlamenta ili Komisije, a upravo obrazloženi prijedlog podrazumijeva nadzorne ovlasti i provođenje odgovarajućih postupaka u tom smislu. ${ }^{15}$ Svakako je takvo negativno Mišljenje, koje je zapravo proglasilo Komisiju uzurpatorom ovlasti koje joj ne pripadaju, ${ }^{16}$ odraz nefunkcionalnog odnosa među institucijama. ${ }^{17}$

Besselink primjećuje kako Okvir za jačanje vladavine prava koristi izraz „praćenje“, dok se u Mišljenju govori o „novom mehanizmu nadzoru“ i naziva se retoričkim trikom. Uzmemo li u obzir da to uistinu nije nepažnja, već nastojanje pravne službe Vijeća da mehanizam nadzora Okvira za jačanje vladavine prava prikaže kao pokušaj stvaranja odnosa subordinacije država u odnosu na Komisiju, ${ }^{18}$ tada nikako ne možemo govoriti o lojalnoj suradnji između institucija Unije.

Ovo nije bio jedini slučaj u kojem je pravna služba vijeća kritizirala Komisiju. Kada je Komisija, 2018. podnijela Prijedlog Uredbe o zaštiti proračuna Unije u slučaju općih nedostataka u pogledu vladavine prava u državama članicama, ${ }^{19}$ ocjena

12 Komunikacija Komisije Europskom parlamentu $i$ Vijeću $\operatorname{COM(2014)~} 0158$ final, pristup 23.11.2020. https://eur-lex.europa.eu/legal-content/HR/TXT/ HTML/?uri=CELEX:52014DC0158\&from=EN.

13 Mišljenje Pravne službe Vijeća 10296/14, pristup 23.11.2020. http://data.consilium.europa.eu/ doc/document/ST-10296-2014-INIT/hr/pdf, 7. i 8.

14 Dmitry Kochenov, Laurent Pech, „Monitoring and Enforcement of the Rule of Law in the EU: Rhetoric and Reality“, European Constitutional Law Review 11, br. 3 (2016): 530, https:// papers.ssrn.com/sol3/papers.cfm?abstract_id=2719755.

15 Leonard F. M. Besselink, „The Bite, the Bark and the Howl Article 7 TEU and the Rule of Law Initiatives", Amsterdam Centre for European Law and Governance research paper, University of Amsterdam br. 1 (2016): 28, https://papers.ssrn.com/sol3/papers.cfm?abstract_id=2715943; Kochenov, Busting the Myths Nuclear, 8, Kochenov, Pech, Monitoring and Enforcement of the Rule of Law in the EU, 531, Schutter, Infringement Proceedings as a Tool for the Enforcement of Fundamental Rights in the European Union, 37.

16 Venetia Argyropoulou, „Enforcing the Rule of Law in the European Union, Quo Vadis EU“, Harvard Human Rights Journal (2019), https://harvardhrj.com/2019/11/enforcing-the-rule-of-law-in-theeuropean-union-quo-vadis-eu/; Kochenov, Pech, Monitoring and Enforcement of the Rule of Law in the EU, 530.

17 U tom smislu vidi Kochenov, Pech, Upholding the Rule of Law in the EU, 10.

18 Besselink, The Bite, the Bark and the Howl Article 7 TEU and the Rule of Law Initiatives, 29.

19 Prijedlog Uredbe Europskog parlamenta $i$ Vijeća o zaštiti proračuna unije u slučaju općih nedostataka u pogledu vladavine prava u državama članicama, COM(2018) 
Pravne službe Vijeća u neobjavljenom mišljenju bila je istovjetna kao u Mišljenju iz 2014. Osnovni je problem što, prema oba mišljenja, Ugovori ne predviđaju dodatne mehanizme zaštite vladavine prava mimo onog u članku 7. UEU-a. ${ }^{20}$ Međutim, postavlja se pitanje je li članak 7. UEU-a jedini mogući mehanizam u tom smislu. Naime, UFEU predviđa takve mehanizme u člancima 258., 259. i 260. koji, što je prihvaćeno i u teoriji ${ }^{21}$ a i u Mišljenju pravne službe Vijeća iz 2014. ${ }^{22}$ nikako nisu neusklađeni s člankom 7. UEU-a. Pritom se članak 7. UEU-a odnosi na sustavna, trajna i teška kršenja vrijednosti iz članka 2. UEU-a, dok se spomenute odredbe UFEU-a odnose na pojedinačna kršenja obveza iz Ugovora. ${ }^{23}$ No, očito je, ako kršenje neke pojedinačne obveze iz Ugovora obuhvaća i povredu vladavine prava da se i te odredbe mogu smatrati mehanizmom za zaštitu vladavine prava. Primjeri za to su predmeti Komisija protiv Mađarske ${ }^{24}$ i Komisija protiv Poljske, ${ }^{25}$ u kojima se neovisnost sudstva, kao dio vladavine prava, branila putem članka 258. UFEU-a. Osim toga, spomenuta presuda Komisija protiv Poljske te presuda ASJP ${ }^{26}$ upravo potvrđuju da članak 7. UEU-a nije jedini put zaštite vrijednosti iz članka 2. UEU-a. ${ }^{27}$ Konačno, ni članak 7. UEU-a ne implicira svoju ekskluzivnost u navedenom smislu. ${ }^{28}$

Odgovor Vijeća na Okvir za jačanje vladavine Komisije bio je dokument naziva „Osiguravanje poštovanja vladavine prava“ koji u točki 14. navodi kako Vijeće nastoji poticati kulturu „poštovanja vladavine prava” konstruktivnim dijalogom među svim državama članicama sukladno s Ugovorima. Nadalje, navodi se kako će se ti ciljevi postići promicanjem dijaloga među svim državama članicama unutar Vijeća,

324 final, pristup 23.11.2020. https://eur-lex.europa.eu/legal-content/HR/TXT/ HTML/?uri=CELEX:52018PC0324\&from=EN, vidi i amandmani koje je usvojio Europski parlament 17. siječnja 2019. o Prijedlogu uredbe Europskog parlamenta i Vijeća o zaštiti proračuna Unije u slučaju općih nedostataka u pogledu vladavine prava u državama članicama (COM(2018)0324 - C8-0178/2018 - 2018/0136(COD)), pristup 23.11.2020., https://www. europarl.europa.eu/doceo/document/TA-8-2019-0038_HR.html.

20 Goldner Lang, The Rule of Law, the Force of Law and the Power of Money in the EU, 20.

21 Vidi, npr. Hillion, Overseeing the rule of law in the European Union Legal mandate and means, 4; Kochenov, Busting the Myths Nuclear, 7; Closa, Kochenov, Weiler, Reinforcing Rule of Law Oversight in the European Union, 9; Dmitry Kochenov, „Article 7: A Commentary on a Much Talked-About 'Dead' Provision“, Polish Yearbook of Inernational Law 38, (2018): 178, http://journals.pan.pl/dlibra/show-content?id=113126\&; Kim Lane Scheppele, Laurent Pech i Daniel R. Kelemen, Never Missing an Opportunity to Miss an Opportunity: The Council Legal Service Opinion on the Commission's EU budget-related rule of law mechanism, 2018., https:// verfassungsblog.de/never-missing-an-opportunity-to-miss-an-opportunity-the-council-legalservice-opinion-on-the-commissions-eu-budget-related-rule-of-law-mechanism/.

22 Mišljenje Pravne službe Vijeća 10296/14, pristup 23.11.2020., http://data.consilium.europa.eu/ doc/document/ST-10296-2014-INIT/hr/pdf, str. 7.

23 Hillion, Overseeing the rule of law in the European Union Legal mandate and means, 9.

24 Presuda od 6. studenog 2012. Komisija protiv Mađarske, C-286/12, ECLI:EU:C:2012:687 (u daljnjem tekstu: Komisija protiv Mađarske).

25 Presuda od 24. lipnja 2019., Europska komisija protiv Poljske, C-619/18, ECLI:EU:C:2019:531 (u daljnjem tekstu: Komisija protiv Poljske).

26 Presuda od 27. veljače 2018., Associação Sindical dos Juízes Portugueses protiv Tribunal de Contas, C-64/16, ECLI:EU:C:2018:117 (u daljnjem tekstu: ASJP).

27 Scheppele, Pech, Kelemen, Never Missing an Opportunity to Miss an Opportunity.

28 Goldner Lang, The Rule of Law, the Force of Law and the Power of Money in the EU, 21. 
uz poštovanje načela objektivnosti, nediskriminacije, jednakog postupanja, na temelju nestranačkog i na dokazima utemeljenog pristupa. U točki 18. navodi se kako će taj „dijalog voditi Vijeće, u sastavu Općih poslova, jednom godišnje“. ${ }^{29}$

Vijeće, dakle, nije podržalo Komisiju. Svojim prijedlogom nazvanim slabim, ${ }^{30}$ bezopasnim, ${ }^{31}$ djetinjastim ${ }^{32}$ pa čak i beskorisnim, ${ }^{33}$ nije učinilo posebno važan iskorak. ${ }^{34}$ Štoviše, imajući u vidu Mišljenje pravne službe Vijeća iz 2014. te takav prijedlog Vijeća koji ne predviđa nikakve nove korake, stječe se dojam da je cilj Vijeća, zapravo sabotirati prijedlog Komisije, kao i da ono nije dostatno odlučno u rješavanju problema država članica koje krše temeljne vrijednosti Unije. ${ }^{35}$ Unatoč svim kritikama, Komisija je svoj Okvir za jačanje vladavine prava iskoristila protiv Poljske prije nego što je 20. prosinca 2017. pokrenula postupak protiv nje.

Spomenimo i kako je u travnju 2019. Komisija donijela Komunikaciju $\operatorname{COM}(2019) 163$ final, Daljnje jačanje vladavine prava u Uniji, ${ }^{36}$ a srpnju 2019. Komunikaciju COM(2019) 343 final, Jačanje vladavine prava u Uniji, ${ }^{37}$ koje nisu donijele konkretnije novosti. ${ }^{38}$ Ipak, zanimljivo je kako se u Komunikaciji COM(2019) 163 final navodi ,kako poštovanje vladavine prava ne ovisi samo o postojanju zakona i institucijskih struktura nego i o institucionalnoj praksi“. Vrijeme će pokazati je li riječ o osvješćivanju Komisije u pogledu lojalne institucijske suradnje kao uvjeta za učinkovitiji članak 7. UEU-a.

Nužno se osvrnuti i na stajalište Parlamenta prema ovim pitanjima. U Rezoluciji od 10. lipnja 2015. Parlament poziva Komisiju da predstavi prijedlog za uspostavu mehanizma EU-a za demokraciju, vladavinu prava i temeljna prava kao instrumenata za provedbu Povelje i ugovorâ i njihovo poštovanje. ${ }^{39}$

U Rezoluciji s preporukama Komisiji o uspostavi mehanizma EU-a za

29 Dokument Vijeća, Osiguravanje poštovanja vladavine prava, 16862/14, pristup 23.11.2020., https://data.consilium.europa.eu/doc/document/ST-16862-2014-INIT/hr/pdf.

30 Šelih, Can EU funds promote the rule of law in Europe?, 5; Argyropoulou, Enforcing the Rule of Law in the European Union, Quo Vadis EU.

31 Gábor Halmai, „The possibility and desirability of economic sanction: Rule of law conditionality requirements against illiberal EU Member States“, EUI Working Papers 6, (2018): 14, http:// dx.doi.org/10.2139/ssrn.3126231.

32 Laurent Pech, „The Rule of Law in the EU: The Evolution of the Treaty Framework and Rule of Law Toolbox", RECONNECT, Working Paper br. 7 (2020): 23, https://reconnect-europe.eu/ wp-content/uploads/2020/03/RECONNECT-WP7-2.pdf.

33 Kochenov, Busting the Myths Nuclear, 11.

34 Kochenov, Pech, Upholding the Rule of Law in the EU, 13.

35 Kochenov, Pech, Monitoring and Enforcement of the Rule of Law in the EU, 534.

36 Komunikacija Komisije COM(2019) 163 final, pristup 23.11.2020., https://eur-lex.europa.eu/ legal-content/HR/TXT/HTML/?uri=CELEX:52019DC0163\&from=EN.

37 Komunikacija Komisije COM(2019) 343 final, pristup 23.11.2020., https://eur-lex.europa.eu/ legal-content/HR/TXT/HTML/?uri=CELEX:52019DC0343\&from=EN.

38 Vidi Dmitry Kochenov, „Elephants in the Room: The European Commission's 2019 Communication on the Rule of Law", The Hague Journal of the Rule of Law 11, (2019): 423438, https://papers.ssrn.com/sol3/papers.cfm?abstract_id=3440957, 433 i dalje.

39 Rezolucija Europskog parlamenta od 10. lipnja 2015. o stanju u Mađarskoj (2015/2700(RSP)), pristup 23.11.2020., https://www.europarl.europa.eu/doceo/document/TA-8-2015-0227_ HR.html. 
demokraciju, vladavinu prava i temeljna prava od 25. listopada 2016. navodi se da „su sve države članice, institucije, tijela, uredi i agencije Unije i zemlje kandidatkinje obvezne poštovati, štititi i promicati ta načela i vrijednosti te imaju dužnost lojalne suradnje“. U točki 6. se podsjeća „da Komisija, kao čuvarica Ugovora, ima dužnost nadzirati i ocjenjivati ispravnu primjenu prava Unije i poštovanje načela i ciljeva iz Ugovora od strane država članica i svih institucija i tijela Unije“.40

Odgovor Komisije ponovno je pokazao da među institucijama Unije razina suradnje nije na zavidnoj razini. Komisija je konstatirala kako ozbiljno sumnja u potrebu takvog mehanizma te je naglasila kako je najbolje iskoristiti postojeće mehanizme, pritom istaknuvši svoj Okvir za jačanje vladavine prava. ${ }^{41}$ Možemo reći da je ono što je Vijeće učinilo Komisiji kada je donijela svoj Okvir za jačanje vladavine prava, Komisija sada učinila Parlamentu.

Dvije godine poslije, 14. studenoga 2018., Parlament je usvojio Rezoluciju o potrebi za sveobuhvatnim mehanizmom EU-a za zaštitu demokracije, vladavine prava i temeljnih prava. Promjena od početnog stajališta Parlamenta vidljiva je već u samom nazivu Rezolucije jer se više ne govori o preporukama, već o potrebi za sveobuhvatnim mehanizmom EU-a. U ovoj se Rezoluciji konstatira da je Komisija 2014. uspostavila okvir za vladavinu prava, no da je taj okvir tek jednom iskorišten te da se pokazao nedostatnim da spriječi ili ukloni prijetnje vladavini prava. ${ }^{42}$ Takva kritika Okvira za jačanje vladavine prava Komisije bila je nešto uvjerljivija od kritike Vijeća. Naime, temeljila se na rezultatima koje je Okvir za jačanje vladavine prava Komisije pokazao. Ono što je, za potrebe ovog rada još važnije jest poziv Parlamenta Vijeću da na odgovarajući način preuzme svoju ulogu u tekućim postupcima u sklopu članka 7. stavka 1. UEU-a. Dakle, iz ove Rezolucije proizlazi očigledno nezadovoljstvo Parlamenta načinom na koji institucije ostvaruju svoje uloge.

Parlament je, kada je riječ o primjeni članka 7. UEU-a, odigrao svoju ulogu. Tako je 12. rujna 2018. Rezoluciju o prijedlogu kojim se Vijeće poziva da, u skladu s člankom 7. stavkom 1. Ugovora o Europskoj uniji, utvrdi očitu opasnost da Mađarska teško prekrši vrijednosti na kojima se temelji Europska unija. ${ }^{43}$ Mađarska je zbog

40 Rezolucija Europskog parlamenta od 25. listopada 2016. s preporukama Komisiji o uspostavi mehanizma EU-a za demokraciju, vladavinu prava i temeljna prava (2015/2254(INL)), pristup 23.11.2020. https://www.europarl.europa.eu/doceo/document/TA-8-2016-0409_HR.html. Vidi i Halmai, The possibility and desirability of economic sanction: Rule of law conditionality requirements against illiberal EU Member States, 14.

41 Odgovor Komisije Europskom parlamentu u vezi Rezolucije od 26. listopada 2016., pristup 23.11.2020. https://oeil.secure.europarl.europa.eu/oeil/popups/ficheprocedure. do?reference=2015/2254(INL)\&l=en\#tab-0; Argyropoulou, Enforcing the Rule of Law in the European Union, Quo Vadis EU.

42 Rezolucija Europskog parlamenta od 14. studenoga 2018. o potrebi za sveobuhvatnim mehanizmom EU-a za zaštitu demokracije, vladavine prava i temeljnih prava (2018/2886(RSP)), pristup 23.11.2020. https://www.europarl.europa.eu/doceo/document/TA-8-2018-0456_ HR.html\#def_1_2.

43 Rezolucija Europskog parlamenta od 12. rujna 2018. o prijedlogu kojim se Vijeće poziva da, u skladu s člankom 7. stavkom 1. Ugovora o Europskoj uniji, utvrdi da postoji očita opasnost da Mađarska teško prekrši vrijednosti na kojima se temelji Europska unija (2017/2131(INL)), pristup 23.11.2020., https://www.europarl.europa.eu/doceo/document/TA-8-2018-0340_HR.html. 
procesnih razloga, konkretno pitanja suzdržanih glasova pri glasovanju u Parlamentu, pokrenula postupak protiv Parlamenta ${ }^{44}$ koji je, u vrijeme pisanja ovog rada, još u tijeku. ${ }^{45}$

Takav je odnos institucija vidljiv i u postupku saslušanja Mađarske i Poljske. Glavno je tajništvo Vijeća 9. srpnja 2019. donijelo Standardne modalitete saslušanja iz članka 7. stavka 1. UEU-a. ${ }^{46}$ Njima je propisano kako je, u slučaju obrazloženog prijedloga jedne trećine država članica, na prvom saslušanju, predstavnik država članica koje su podnijele obrazloženi prijedlog taj prijedlog za što ima na raspolaganju, u pravilu, najviše dvadeset minuta, a jednako vrijedi i u slučaju obrazloženog prijedloga Komisije. Za Parlament, međutim, predstavljanje obrazloženog prijedloga uopće nije predviđeno. Takav je diskriminirajući odnos prema Parlamentu propisan Standardnim modalitetima saslušanja, ${ }^{47}$ pokazatelj nekvalitetnog odnosa institucija Unije, koji se nikako ne bi mogao opisati lojalnom suradnjom. Ovo je još više došlo do izražaja u još jednom Mišljenju pravne službe Vijeća koje se protivilo da se predstavnici Parlamenta Judith Sargentini dopusti izložiti svoje izvješće Vijeću. ${ }^{48}$ Njezino je izvješće sadržavalo prijedlog Rezolucije o prijedlogu kojim se Vijeće poziva da, u skladu s člankom 7. stavkom 1. Ugovora o Europskoj uniji, utvrdi da postoji očita opasnost da Mađarska teško prekrši vrijednosti na kojima se temelji Europska unija. ${ }^{49}$ Predstavnica je svoje izvješće ipak izložila, ali na neformalnom sastanku. ${ }^{50}$

U Rezoluciji Europskog parlamenta od 16. siječnja 2020. o saslušanjima u tijeku u skladu s člankom 7. stavkom 1. UEU-a u pogledu Poljske i Mađarske (2020/2513(RSP)) članovi Parlamenta su sa zabrinutošću primijetili da se saslušanja ne održavaju redovito niti su organizirana na strukturiran i otvoren način, ističući da saslušanja moraju biti objektivna, utemeljena na činjenicama i transparentna te da države članice moraju tijekom postupka surađivati u dobroj vjeri u skladu s načelom lojalne suradnje iz članka 4. stavka 3. UEU-a. ${ }^{51}$ Osim toga, izražena je duboka zabrinutost zbog toga što se Standardnim modalitetima saslušanja ne osigurava da se prema Parlamentu postupa jednako kao prema Komisiji i jednoj trećini država članica

44 Pech, The Rule of Law in the EU, 26.

45 Predmet. Mađarska protiv Parlamenta, C-650/18.

46 Standardni modaliteti saslušanja iz članka 7. stavka 1. UEU-a 10641/2/19, pristup 23.11.2020., https://data.consilium.europa.eu/doc/document/ST-10641-2019-REV-2/hr/pdf.

47 Kochenov, Article 7, 169; Laurent Pech, From ,, Nuclear Option “ to Damp Squid, 2019., pristup 23.11.2020. , https://verfassungsblog.de/from-nuclear-option-to-damp-squib/.

48 Kochenov, Article 7, 169; Kochenov, Bard, The Last Soldier Standing?, 5.

49 Izvješće od 4.7.2018. o prijedlogu kojim se Vijeće poziva da, u skladu s člankom 7. stavkom 1. Ugovora o Europskoj uniji, utvrdi da postoji očita opasnost da Mađarska teško prekrši vrijednosti na kojima se temelji Europska unija (2017/2131(INL), pristup 23.11.2020., https:// www.europarl.europa.eu/doceo/document/A-8-2018-0250_HR.html.

50 Daniel D. Hegedüs, „What Role for EU Institutions In Confronting Europe's Democracy and Rule of Law Crisis?", German Marshall Fund of the United States 4 (2019): 8, https://www. gmfus.org/sites/default/files/publications/pdf/Confronting\%20Europe\%E2\%80\%99s\%20 Democracy\%20and\%20Rule\%20of\%20Law\%20Crisis.pdf.

51 Rezolucija Europskog parlamenta od 16. siječnja 2020. o saslušanjima u tijeku u skladu s člankom 7. stavkom 1. UEU-a u pogledu Poljske i Mađarske (2020/2513(RSP)), pristup 23.11.2020., https://www.europarl.europa.eu/doceo/document/TA-9-2020-0014_HR.html, t. 1. 
kad je riječ o predstavljanju obrazloženog prijedloga. Također, u ovoj Rezoluciji u Parlamentu se skreće pozornost na to da Vijeće nije učinkovito primijenilo članak 7. UEU-a zbog čega su i dalje ugroženi integritet zajedničkih europskih vrijednosti, uzajamno povjerenje i vjerodostojnost Unije kao cjeline te se poziva Komisija i Vijeće da bez odgode započnu pregovore s Parlamentom o međuinstitucijskom sporazumu, ponovno ističući da mehanizam treba dopuniti i ojačati, a ne zamijeniti postojeće $i$ buduće postupke u skladu s člankom 7. UEU-a. ${ }^{52}$

U svojem Priopćenju za tisak od 16. siječnja 2020., Parlament je zaključio da se stanje vladavine prava u Mađarskoj i Poljskoj pogoršava..$^{53}$

Nedjelotvornost članka 7. UEU-a očiti je primjer neodržavanja lojalne suradnje koju su institucije Unije dužne održavati sukladno s člankom 13. stavak 2. UEU-a. Naime, razlozi zašto se članak 7. UEU-a teško pokreće i zašto, i nakon što je pokrenut ne dovodi do konkretnih rezultata, nije zbog teksta članka, već je u nedostatku istinske želje institucija, odnosno država članica da taj rezultat bude postignut. ${ }^{54}$

Kada govorimo o institucijama, očito je da među njima postoji suparništvo. ${ }^{55}$ Ovo je dolazilo do izražaja od samih početaka članka 7. UEU-a. Pravna služba Vijeća oštro je kritizirala Komisijin Okvir za jačanje vladavine prava iz 2014., kao i Prijedlog Uredbe o zaštiti proračuna Unije u slučaju općih nedostataka u pogledu vladavine prava u državama članicama iz 2018. iz, kako je u radu već opisano, ne odveć uvjerljivih razloga.$^{56}$ Također, ako je Besselink u pravu kada kaže da je pravna služba Vijeća izraz „praćenje“ namjerno zamijenila izrazom „nadziranje“ kako bi Komisijin Okvir prikazala u negativnom svjetlu, onda uistinu možemo govoriti o ozbiljnoj razini rivaliteta između institucija. ${ }^{57}$

S druge strane, umjesto potpore Komisiji po pitanju njenog Okvira, za jačanje vladavine prava, ${ }^{58}$ što bi bilo u skladu s člankom 13. stavkom 2. UEU-a, Vijeće je usvojilo „Osiguravanje poštovanja vladavine prava“, potpuno ignorirajući Komisiju i njezin prijedlog. ${ }^{59}$

I odnos Parlamenta i Vijeća nije bio puno bolji. To je posebno vidljivo u Standardnim modalitetima saslušanja iz članka 7. stavka 1. UEU-a koje je Parlament stavilo u neravnopravni položaj u odnosu na Komisiju i države članice kada je riječ o podnošenju obrazloženoga prijedloga iz članka 7. stavka 1 . UEU-a ${ }^{60}$ ali i u slučaju

52 Rezolucija Europskog parlamenta od 16. siječnja 2020. o saslušanjima u tijeku u skladu s člankom 7. stavkom 1. UEU-a u pogledu Poljske i Mađarske (2020/2513(RSP)), pristup 23.11.2020., https://www.europarl.europa.eu/doceo/document/TA-9-2020-0014_HR.html, t. 2., 3. i 5 .

53 Priopćenje za tisak Parlamenta od 16.1.2020., Pogoršava se stanje vladavine prava u Poljskoj $i$ Mađarskoj, pristup 23.11.2020., https://www.europarl.europa.eu/news/hr/pressroom/20200109IPR69907/pogorsava-se-stanje-vladavine-prava-u-poljskoj-i-madarskoj.

54 Kochenov, Elephants in the Room, 427.

$55 \mathrm{U}$ tom smislu, Halmai, The possibility and desirability of economic sanction, 14.

56 Vidi, npr. Kochenov, Busting the Myths Nuclear, 8; Scheppele, Pech, Kelemen, Never Missing an Opportunity to Miss an Opportunity.

57 Besselink, The Bite, the Bark and the Howl Article 7 TEU and the Rule of Law Initiatives, 29.

58 Kochenov, Pech, Monitoring and Enforcement of the Rule of Law in the EU, 534.

59 Pech, The Rule of Law in the EU, 23.

60 Kochenov, Article 7, 169. 
saslušanja predstavnice Sargentini. Ni za Komisiju se ne može reći da je bila sklona suradnji kada je Parlament, u listopadu 2016., usvojio Rezoluciju s preporukama Komisiji o uspostavi mehanizma EU-a za demokraciju, vladavinu prava i temeljna prava ${ }^{61}$ Naposljetku, ni Parlament se, u svojim rezolucijama, nije suzdržavao kritika drugih institucija Unije. ${ }^{62}$

Dakle, uočen je rivalitet među institucijama i svakako utječe na učinkovitost članka 7. UEU-a. Može se zaključiti i kako je razlog tome činjenica da institucije predstavljaju različite interese. Komisija predstavlja Uniju, Europski parlament građane Unije, odnosno državljane država članica, a Vijeće i Europsko Vijeće interese država članica. ${ }^{63}$

Po prirodi stvari Komisija bi trebala biti najangažiranija kod kršenja temeljnih vrijednosti od strane država članica. ${ }^{64}$ Naime, nepostojanje vladavine prava u nekoj državi članici vrlo će vjerojatno negativno utjecati i na normalno djelovanje zajedničkog tržišta, temelja Europske unije ${ }^{65}$ I Europski parlament trebao bi biti osjetljiviji na određene napade na vladavinu prava i ostale vrijednosti iz članka 2. UEU-a. Ipak, u Parlamentu se moguće koalicije pojedinih stranaka iz država članica koje spadaju u skupinu „neposlušnih“ država članica. Vijeće će biti manje sklono pokretanju postupka iz članka 7. UEU-a ${ }^{66}$ te će se države članice međusobno štititi od mogućih scenarija u kojima prema svakoj od njih, u budućnosti, može biti pokrenut takav postupak. ${ }^{67}$

Imajući u vidu tu okolnost, kao i opisane sukobe institucija Unije kad je bila riječ o primjeni članka 7. UEU-a te činjenicu da Vijeće dosad nije ostvarilo svoje ovlasti iz članka 7. UEU-a, možemo se složiti s konstatacijom da je, od svih institucija Unije, Vijeće najodgovornije za neučinkovitost navedenoga članka.$^{68}$ Konačno, i Komisija i Parlament, odigrali su svoju ulogu predviđenu člankom 7. stavkom 1. UEU-a.

Svakako je očito da u ovom kontekstu institucije ne poštuju obvezu lojalne

61 Odgovor Komisije Europskom parlamentu u vezi Rezolucije od 26. listopada 2016.,pristup 23.11.2020., https://oeil.secure.europarl.europa.eu/oeil/popups/ficheprocedure.do?reference= 2015/2254(INL)\&l=en\#tab-0.

62 Vidi; npr. Rezolucija Europskog parlamenta od 14. studenoga 2018. o potrebi za sveobuhvatnim mehanizmom EU-a za zaštitu demokracije, vladavine prava i temeljnih prava (2018/2886(RSP)), pristup 23.11.2020., https://www.europarl.europa.eu/doceo/document/TA8-2018-0456_HR.html\#def_1_2 ili Rezolucija Europskog parlamenta od 16. siječnja 2020. o saslušanjima u tijeku u skladú s člankom 7. stavkom 1. UEU-a u pogledu Poljske i Mađarske (2020/2513(RSP)), pristup 23.11.2020., https://www.europarl.europa.eu/doceo/document/TA9-2020-0014_HR.html.

63 Eleonora Camela, „The Rule of Law Erosion in the EU: Are We Solidly Built to Hinder It?“, Between Ineffective Tools and New Approaches (2019): 16, https://papers.ssrn.com/sol3/papers. cfm?abstract_id=3449979; Balázs Fekete, „On Article 7 TEU: Context, History, Doctrine and Shortcomings", Hungarian Academy of Sciences (HAS), (2017): 14, http://dx.doi.org/10.2139/ ssrn.3061958.

64 Kochenov, Elephants in the Room, 433.

$65 \mathrm{U}$ tom smislu vidi Šelih, Can EU funds promote the rule of law in Europe?, 3.

66 Kochenov, Article 7, 170.

67 Fekete, On Article 7 TEU, 15.

68 Kochenov, Article 7, 169; Kochenov, Bard, The Last Soldier Standing?, 5. 
suradnje iz članka 13. stavka 2. UEU-a. ${ }^{69}$

\section{SUPARNIŠTVO INSTITUCIJA I SUD EU-A}

Za lojalnu suradnju koja obvezuje institucije vrijede ista pravila kao i za lojalnu suradnju iz članka 4. stavka 3. UEU-a, ${ }^{70}$ kako je potvrdio i Sud EU-a. ${ }^{71}$ To znači i da su institucije obvezne poduzimati sve odgovarajuće mjere, opće ili posebne, kako bi osigurale ispunjavanje obveza koje proizlaze iz Ugovora, odnosno olakšavati ostvarivanje zadaća Unije i suzdržavati se od svake mjere koja bi mogla ugroziti postizanje ciljeva Unije. ${ }^{72}$ Odnos između institucija kako je prikazan u ovom radu, nikako se ne bi mogao podvesti pod ispunjavanje tih obveza. Načelo lojalne suradnje podrazumijevalo bi pokušaj institucija da zajedničkim djelovanjem dođu do cilja, a to je učinkovitost članka 7. UEU-a te, u konačnici, optimalan stupanj poštovanja vladavine prava u Europskoj uniji. Kako je prikazano u prethodnom poglavlju, međusobne kritike koje su si institucije upućivale prije bi se mogle opisati kao sabotiranje, nego kao lojalna suradnja. Umjesto pronalaženja učinkovitog mehanizma za rješavanje problema, institucije su gubile vrijeme na rasprave o međusobnim nadležnostima, odnosno nenadležnostima u sklopu postupaka iz članka 7. UEU-a.

Isto tako, činjenica da se Standardnim modalitetima saslušanja ne osigurava da se prema Parlamentu postupa jednako kao prema Komisiji i jednoj trećini država članica kad je riječ o predstavljanju obrazloženog prijedloga, mogla bi dovesti i do toga da se prijedlog Parlamenta uopće ne prihvati.

Nedostatak lojalne suradnje institucija Unije svakako nije jedini razlog neučinkovitosti članka 7. UEU-a, no kako proizlazi iz prikazanog, pokazao se kao čimbenik koji pridonosi njegovoj neučinkovitosti.

$\mathrm{S}$ tim se problemom Sud EU-a i ranije susretao u svojoj praksi. U presudi GPS Vijeće je usvojilo uredbu bez pribavljanja mišljenja Parlamenta. Krajem listopada 1992., Vijeće je iz, kako je zaključio Sud EU-a, opravdanih razloga upozorilo Parlament da dotična uredba treba biti usvojena do kraja 1992. te stupiti na snagu 1. siječnja 1993. Parlament nije uzeo u obzir upozorenje Vijeća te je odgodio sjednicu na kojoj se o tom pitanju trebalo odlučivati. Vijeće je, neovisno o Parlamentu, usvojilo uredbu što je Sud EU-a smatrao ispravnom odlukom te je zaključio da je Parlament taj koji nije ispunio obvezu lojalne suradnje s Vijećem. ${ }^{73}$

69 Hillion, Overseeing the rule of law in the European Union Legal mandate and means, 14.

70 Peter Van Elsuwege, „The Duty of Sincere Cooperation and Its Implications for Autonomous Member State“, Action in the Field of External Relations: Member State Interests and European Union Law (2019): 286, https://www.researchgate.net/publication/330961755_The_Duty_ of_Sincere_Cooperation_and_Its_Implications_for_Autonomous_Member_State_Action_ in_the_Field_of_External_Relations_Member_State_Interests_and_European_Union_Law; Hillion, Overseeing the rule of law in the European Union Legal mandate and means, 3.

71 Npr., Presuda od 27. rujna 1988., Grčka protiv Vijeća Europskih zajednica, C- 204/86, ECLI:EU:C:1988:450, para. 16.

72 Christophe Hillion, Conferral, cooperation and balance in the institutional framework of the EU external action (2017), 24, https://papers.ssrn.com/sol3/papers.cfm?abstract_id=2917203.

73 Presuda od 30. ožujka 1995., Parlament protiv Vijeća Europske unije, C-65/93, ECLI:EU:C:1995:91, para. 24., 26. i 27.; Hillion, Conferral, cooperation and balance in the 
U presudi Makrofinancijska pomoć Sud EU-a bavio se pitanjem je li Komisija donošenjem odluke o povlačenju Prijedloga uredbe Europskog parlamenta i Vijeća o utvrđivanju općih odredbi vezanih za makrofinancijsku pomoć trećim zemljama, povrijedila, između ostalog, načelo lojalne suradnje. Na nekoliko sastanaka Parlamenta, Vijeća i Komisije, Parlament i Vijeće sporazumjeli su se oko zamjene Komisijine provedbene ovlasti, dugotrajnijim redovnim zakonodavnim postupkom u cilju donošenja odluka o dodjeli pomoći (MFA), zbog čega je Komisija najavila mogućnost povlačenja prijedloga, što je i učinila. ${ }^{74}$

Sud EU-a zaključio je da načelo institucionalne ravnoteže nije narušeno i to iz dva razloga. Prvo, Komisija je, prema zaključku Suda ,imala pravo smatrati da je izmjena koju su predvidjeli Parlament i Vijeće što se tiče članka 7. prijedloga okvirne uredbe mogla iskriviti taj prijedlog, vezano uz ključno pitanje postupka dodjele MFAa, na način koji bi spriječio ostvarivanje ciljeva koje je Komisija nastojala postići spomenutim prijedlogom i koji bi stoga potonjemu oduzeli njegov razlog postojanja“ ${ }^{75}$ Drugo, Komisija nije povukla svoj prijedlog prije no što se uvjerila da su Vijeće i Parlament imali na umu taj prijedlog izmijeniti na način koji je bio suprotan ciljevima koje je on nastojao postići, nije isključila mogućnost bilo kakve rasprave $\mathrm{u}$ vezi s tim te nije prekasno najavila namjeru povlačenja. ${ }^{76}$

I u presudi Staklenički plinovi u Australiji Sud EU-a potvrdio je važnost lojalne suradnje između institucija, naglasivši kako je lojalna suradnja osobit važna kada je riječ o djelovanju Unije na međunarodnom planu. ${ }^{77}$

U presudi ITLOS Sud EU-a naglasio je kako, s obzirom na članak 13. stavak 2. UEU-a, odnosno načelo lojalne suradnje, Komisija je obvezna prethodno se savjetovati $\mathrm{s}$ Vijećem kada namjerava iznijeti stajališta u ime Unije pred međunarodnim sudom. ${ }^{78}$

Posebno je važno mišljenje nezavisne odvjetnice Sharpston u predmetu Dopuna Memoranduma o razumijevanju. ${ }^{79}$ Komisija je donijela Odluku o potpisivanju Dopune Memorandumu o razumijevanju o financijskom doprinosu Švicarske Konfederacije na temelju članka 17. UEU-a, bez sudjelovanja Vijeća, zbog čega je Vijeće tražilo poništenje te odluke. ${ }^{80}$

Nezavisna odvjetnica Sharpston zaključila je da je Komisija uistinu postupila

institutional framework of the EU external action, 8.

74 Presuda od 14. travnja 2015., Vijeće Europske unije protiv Europske komisije, C-409/13, ECLI:EU:C:2015:217, para, 18-26. (u daljnjem tekstu: Makrofinancijska pomoć).

75 Makrofinancijska pomoć, para. 94.

76 Makrofinancijska pomoć, para. 98., 103. i 105. Vidi i Hillion, Conferral, cooperation and balance in the institutional framework of the EU external action, 23.

77 Presuda od 16. srpnja 2015., Europska komisija protiv Vijeća Europske unije, C-425/13, ECLI:EU:C:2015:483, para. 64.

78 Presuda od 6. listopada 2015., Vijeće Europske unije protiv Europske komisije C-73/14, ECLI:EU:C:2015:663, para. 86.

79 Mišljenje nezavisne odvjetnice Sharpston od 26. studenog 2015. u predmetu Vijeće Europske unije protiv Europske komisije, C-660/13, ECLI:EU:C:2015:787 (u daljnjem tekstu: Dopuna Memoranduma o razumijevanju, mišljenje).

80 Presuda od 28. srpnja 2016., Vijeće Europske unije protiv Europske komisije, C-660/13, ECLI:EU:C:2016:616 (u daljnjem tekstu: Dopuna Memoranduma o razumijevanju), para. $2-16$. 
protivno načelu lojalne suradnje, međutim da Vijeće nije dokazalo da je ta povreda dovela do njezine manjkavosti te da je dostatno da je se poništi. Nastavno je zaključila da bi, u odgovarajućim okolnostima, postupanje koje je prethodilo donošenju nekog akta, a koje je suprotno načelu lojalne suradnje, moglo utjecati na sadržaj ili oblik akta te, time predstavljati ispravan temelj za njegovo poništenje. ${ }^{81}$ Sud EU-a, u konkretnom slučaju, poništio je odluku zbog nedostatka suglasnosti Vijeća ne ulazeći u pitanje lojalne suradnje. ${ }^{82}$

Praksa Suda EU-a očigledno pokazuje kako je načelo lojalne suradnje za institucije Unije jednako važno kao i za države članice te je više puta i zaštitio isto načelo. Postavlja se pitanje bi li ga Sud EU-a mogao štititi i kada se institucije ne pridržavaju toga načela u vezi s pokretanjem članka 7. UEU-a.

U presudi Bertelli Gálvez, Sud EU-a zaključio je da na temelju Ugovora nema ovlast odlučivati jesu li institucije postupale u skladu s Ugovorima i osigurale poštovanje vrijednosti iz današnjeg članka 2 . UEU-a, odnosno odlučivati o zakonitosti akata usvojenih na temelju članka 7. UEU-a, ${ }^{83}$ a u tom smislu se govori i u rješenju u predmetu $M L P S{ }^{84}$ Ovo se, naravno, ne odnosi na nadležnost Suda EU-a da odlučuje o postupovnim pitanjima na temelju članka 269. UFEU-a, s čim se u vezi i trenutačno vodi konkretni postupak..$^{85}$

Drugo je, međutim, pitanje odnosa institucija i poštovanja načela lojalne suradnje. Naime, ova obveza institucija postoji uvijek, neovisno o području njihova djelovanja. ${ }^{86}$ Ako je Parlament pokrenuo postupak protiv države članica, a Vijeće ne zakazuje saslušanja ili ga bilo kako diskriminira tijekom toga postupka, nema razloga da Parlament protiv Vijeća ne pokrene postupak, naravno kad se zadovolje sve procesne pretpostavke. Isto vrijedi i za ostale institucije Unije. Tako pokrenut postupak ne bi trebao imati isti ishod kao i predmet Bertelli Gálvez, jer se on ne bi odnosio na djelovanje, odnosno nedjelovanje institucija po članku 7.UEU-a, već bi se odnosio isključivo na nelojalnu suradnju, odnosno na odnos institucija Unije koji nikako ne može biti obuhvaćen obvezom iz članka 13. stavka 2. kako ju je tumačio Sud EU-a. Naravno, prvi i osnovni preduvjet za ovo jest volja za pokretanjem postupka institucije koja je povrijeđena djelovanjem ili nedjelovanjem druge institucije.

Iako se Sud EU-a pokazao najučinkovitijim zaštitnikom temeljnih vrijednosti iz članka 2. UEU-a, ${ }^{87}$ zasad nije bio u prilici učiniti to osnaživanjem članka 7. UEU-a.

81 Dopuna Memoranduma o razumijevanju, mišljenje, para. 135.-138., Hillion, Conferral, cooperation and balance in the institutional framework of the EU external action, 29.

82 Dopuna Memoranduma o razumijevanju, para. 46.

83 Presuda od 2. travnja 2004., Bertelli Gálvez, T-337/03, ECLI:EU:T:2004:106, para. 15.; Kochenov, Pech, Monitoring and Enforcement of the Rule of Law in the EU, 517.

84 Presuda od 11. srpnja 2019., Europska komisija protiv Republike Italije, C-304/18, ECLI:EU:C:2019:601; Pech, The Rule of Law in the EU, 26.

85 Predmet Mađarska protiv Parlamenta C-650/18.

86 Hillion, Conferral, cooperation and balance in the institutional framework of the EU external action, 58.

87 Kochenov, Elephants in the Room, 424; Kochenov, Article 7, 170; Michał Krajewski, „Associação Sindical dos Juízes Portugueses: The Court of Justice and Athena's Dilemma“, European Papers 3, br. 1 (2018): 402, https://www.researchgate.net/publication/325793453 Associacao_Sindical_dos_Juizes_Portugueses_The_Court_of_Justice_and_Athena's_ 
Ako bi, u sklopu postupka pokrenutog na temelju članka 7. UEU-a neka institucije protiv druge pokrenula postupak na temelju članka 263. UFEU-a, zbog nepoštovanja načela lojalne suradnje, Sud EU-a mogao bi neizravno osnažiti članak 7. UEU-a.

\section{ZAKLJUČAK}

Članak 7. UEU-a posljedica je političkih zbivanja u Europskoj uniji i njezinim državama članicama. Zamišljen je kao sredstvo rješavanja problema država članica koje teško i trajno krše temeljne vrijednosti Unije, odnosno u odnosu na koje postoji očita opasnost da teško krše te vrijednosti. Zbog sankcija koje predviđa, članak je nazvan ,nuklearnom opcijom“. Unatoč višegodišnjim situacijama u Mađarskoj i Poljskoj koje su se opisivale kao kršenje temeljnih vrijednosti Unije, ${ }^{88}$ Komisija je pokrenula, tzv. preventivni mehanizam iz članka 7. stavka 1. UEU-a protiv Poljske tek u prosincu 2017., dok je Parlament taj isti postupak pokrenuo protiv Mađarske u rujnu 2018. Do danas, osim što je održano nekoliko saslušanja s Poljskom i Mađarskom, daljnjih koraka nije bilo.

Kritike, upitne utemeljenosti, koje je pravna služba Vijeća upućivala nastojanjima Komisije da poboljša zaštitu temeljnih vrijednosti Unije putem članka 7 .UEU-a, ${ }^{89}$ ignoriranje takvih nastojanja ${ }^{90}$ pa čak i međusobno diskriminiranje, ${ }^{91}$ obilježile su suradnju institucija Unije kada je riječ o provođenju članka 7. UEU-a. Obveza lojalne suradnje za institucije Unije postoji uvijek, neovisno o području njihova djelovanja. ${ }^{92}$ Praksa Suda EU-a pokazuje kako je obveza lojalne suradnje za institucije Unije jednako važna kao i za države članice te je više puta i zaštitio to načelo u odnosu na institucije. $^{93}$

To znači da bi Sud EU-a, osuđujući nelojalnu institucijsku suradnju u primjeni članka 7. UEU-a, mogao posredno osnažiti taj članak, a da prekorači granice svoje nadležnosti koje mu postavlja članak 269. UFEU-a. ${ }^{94}$

Dilemma.

88 Vidi, npr. Kochenov, Busting the Myths Nuclear, 12.

89 Vidi, npr. Kochenov, Busting the Myths Nuclear, 8; Scheppele, Pech, Kelemen, Never Missing an Opportunity to Miss an Opportunity.

90 Kochenov, Pech, Monitoring and Enforcement of the Rule of Law in the EU, 534; Pech, The Rule of Law in the EU, 23.

91 Kochenov, Article 7, 169.

92 Hillion, Conferral, cooperation and balance in the institutional framework of the EU external action, 58.

93 Vidi, npr. presuda od 14.6.2016., Europski parlament protiv Vijeća Europske unije, C-263/14, ECLI:EU:C:2016:435

94 Rukopis je predan na objavu prije 30. rujna 2020. godine kada je objavljeno Godišnje izvješće Komisije o vladavini prava za 2020. 


\section{LITERATURA}

\section{Knjige i članci}

1. Argyropoulou, Venetia. „Enforcing the Rule of Law in the European Union, Quo Vadis EU“. Harvard Human Rights Journal (2019), https://harvardhrj.com/2019/11/enforcing-the-ruleof-law-in-the-european-union-quo-vadis-eu/.

2. Besselink, Leonard F. M. „Bite, the Bark and the Howl Article 7 TEU and the Rule of Law Initiatives“. Amsterdam Centre for European Law and Governance research paper, University of Amsterdam br. 1 (2016): 3-39, https://papers.ssrn.com/sol3/papers. cfm?abstract id $=2715943$.

3. Bugarič, Bojan. „Protecting Democracy and the Rule of Law in the European Union: The Hungarian Challenge“. LEQS Paper br. 79 (2014): 1-39, http://dx.doi.org/10.2139/ ssrn.2466340.

4. Camela, Eleonora. The Rule of Law Erosion in the EU: Are We Solidly Built to Hinder It?. Between Ineffective Tools and New Approaches. https://papers.ssrn.com/sol3/papers. cfm?abstract_id=3449979.

5. Closa, Carlos, Dimitry Kochenov, Joseph H. H. Weiler. „Reinforcing Rule of Law Oversight in the European Union“. Robert Schuman Centre for Advanced Studies Research 25, (2014): 1-33, https://papers.ssrn.com/sol3/papers.cfm?abstract_id=2404260

6. Dani, Marco. Opening the enforcement of EU fundamental values to European citizens. 2013., pristup 23.11.2020. https://verfassungsblog.de/opening-the-enforcement-of-eufundamental-values-to-european-citizens/.

7. De Schutter, Olivier. „Infringement Proceedings as a Tool for the Enforcement of Fundamental Rights in the European Union“. Open Society European Policy Institute. Open Society Foundations (2017): 7-67, https://www.opensocietyfoundations.org/ uploads/f637765b-ee20-4e6e-9cda-b74151f9a369/infringement-proceedings-as-tool-forenforcement-of-fundamental-rights-in-eu-20171214.pdf.

8. De Witte, Floris. Less Constraint of Popular Democracy, More Empowerment of Citizens, 2013., https://verfassungsblog.de/less-constraint-of-popular-democracy-moreempowerment-of-citizens/\#.UX5E80a2iM8.

9. Fekete, Balázs. „On Article 7 TEU: Context, History, Doctrine and Shortcomings“. Hungarian Academy of Sciences (HAS) (2017): 1-18, https://papers.ssrn.com/sol3/papers. cfm?abstract id $=3061958$.

10. Goldner Lang, Iris. „The Rule of Law, the Force of Law and the Power of Money in the EU“. Croatian Yearbook of European Law \& Policy 15, br. 1 (2019): 1-26.

11. Halmai, Gábor. „The possibility and desirability of economic sanction: Rule of law conditionality requirements against illiberal EU Member States“. EUI Working Papers 6, (2018): 1-20, http://dx.doi.org/10.2139/ssrn.3126231.

12. Hegedüs, Daniel. „What Role for EU Institutions In Confronting Europe's Democracy and Rule of Law Crisis?". German Marshall Fund of the United States 4, (2019): 2-17, $\quad$ https://www.gmfus.org/sites/default/files/publications/pdf/Confronting\%20 Europe $\%$ E2\%80\%99s\%20Democracy\%20and\%20Rule\%20of\%20Law\%20Crisis.pdf.

13. Hillion, Christophe. Conferral, cooperation and balance in the institutional framework of the EU external action (2017): 1-73, https://papers.ssrn.com/sol3/papers.cfm?abstract id $=2917203$.

14. Hillion, Christophe. „Overseeing the rule of law in the European Union Legal mandate and means". Swedish Institute for European Policy Studies, European Policy Analysis (2016): 1-14, https://www.sieps.se/en/publications/2016/overseeing-the-rule-of-law-inthe-european-union-legal-mandate-and-means-20161epa/Sieps_2016_1_epa?

15. Hotham, Leo i Lucas Nacif. „Article 7 TEU and the Polish case - a recast". KSLR EU Law Blog 2018., https://blogs.kcl.ac.uk/kslreuropeanlawblog/?p=1274\#.XxaUNJ4zaUm. 
16. Kochenov, Dimitry. „Article 7: A Commentary on a Much Talked-About 'Dead' Provision". Polish Yearbook of Inernational Law 38, (2018): 165-187, http://journals.pan. $\mathrm{pl} / \mathrm{dlibra} /$ show-content?id=113126\&.

17. Kochenov, Dimitry. „Busting the Myths Nuclear: A Commentary on Article 7 TEU“. EUI Working Papers 10, br. 8 (2017): 1-13., http://dx.doi.org/10.2139/ssrn.2965087.

18. Kochenov, Dimitry. „Elephants in the Room: The European Commission's 2019 Communication on the Rule of Law“. The Hague Journal of the Rule of Law 11, (2019): 423-438, https://papers.ssrn.com/sol3/papers.cfm?abstract_id=3440957.

19. Kochenov, Dimitry, Petra Bard. „The Last Soldier Standing? Courts vs. Politicians and the Rule of Law Crisis in the New Member States of the EU“. European Yearbook of Constitutional Law 1, (2019): 1-39, https://papers.ssrn.com/sol3/papers.cfm?abstract $\mathrm{id}=3339631$.

20. Kochenov, Dimitry i Laurent Pech. „Monitoring and Enforcement of the Rule of Law in the EU: Rhetoric and Reality". European Constitutional Law Review 11, br. 3 (2016): 512-540, https://papers.ssrn.com/sol3/papers.cfm?abstract_id=2719755.

21. Kochenov, Dimitry, Laurent Pech. „Upholding the Rule of Law in the EU: On the Commission's 'Pre-Article 7 Procedure' as a Timid Step in the Right Direction". EUI Working Papers br. 24 (2015): 1-16, https://cadmus.eui.eu/bitstream/handle/1814/35437/ RSCAS_2015_24.pdf.

22. Krajewski, Michał. „Associação Sindical dos Juízes Portugueses: The Court of Justice and Athena's Dilemma“. European Papers 3, br. 1, (2018): 395-407, https://www. researchgate.net/publication/325793453_Associacao_Sindical_dos_Juizes_Portugueses_ The_Court_of_Justice_and_Athena's_Dilemma.

23. Müller, J. W., Should the EU Protect Democracy and the Rule of Law Inside Member States? http://www.princeton.edu/ jmueller/ELJ-Democracy\%20Protection-JWMuellerpdf.

24. Pech, Laurent. From „Nuclear Option“ to Damp Squid, 2019., https://verfassungsblog. de/from-nuclear-option-to-damp-squib/.

25. Pech, Laurent. „The Rule of Law in the EU: The Evolution of the Treaty Framework and Rule of Law Toolbox". RECONNECT, Working Paper br. 7 (2020): 5-34, https:// reconnect-europe.eu/wp-content/uploads/2020/03/RECONNECT-WP7-2.pdf.

26. Scheppele, Kim Lane, Laurent Pech, i Daniel R. Kelemen. Never Missing an Opportunity to Miss an Opportunity: The Council Legal Service Opinion on the Commission's EU budget-related rule of law mechanism, 2018., https://verfassungsblog.de/never-missingan-opportunity-to-miss-an-opportunity-the-council-legal-service-opinion-on-thecommissions-eu-budget-related-rule-of-law-mechanism/.

27. Šelih, Jasna, Ian I. Bond, i Carl Dolan. „Can EU funds promote the rule of law in Europe?". Centre for European Reform (2017): 1-14, https://www.cer.eu/sites/default/ files/pbrief_structural_funds_nov17.pdf.

28. Van Elsuwege, Peter. The Duty of Sincere Cooperation and Its Implications for Autonomous Member State Action in the Field of External Relations: Member State Interests and European Union Law, (2019): 283-298, https://www.researchgate.net/ publication/330961755_The_Duty_of_Sincere_Cooperation_and_Its_Implications_for Autonomous_Member_State_Action_in_the_Field_of_External_Relations_Member_ State_Interests_and_European_Union_Law.

Pravna vrela

1. Amandmani koje je usvojio Europski parlament 17. siječnja 2019. o Prijedlogu Uuredbe Europskog parlamenta $i$ Vijeća o zaštiti proračuna Unije u slučaju općih nedostataka u pogledu vladavine prava u državama članicama (COM(2018)0324 - C8-0178/2018 - 2018/0136(COD)), pristup 23.11.2020., dostupno na https://www.europarl.europa.eu/ doceo/document/TA-8-2019-0038_HR.html. 
2. Dokument Vijeća, Osiguravanje poštovanja vladavine prava, 16862/14, pristup 23.11.2020., dostupno na https://data.consilium.europa.eu/doc/document/ST-168622014-INIT/hr/pdf.

3. Izvješće od 4.7.2018. o prijedlogu kojim se Vijeće poziva da, u skladu s člankom 7. stavkom 1. Ugovora o Europskoj uniji, utvrdi da postoji očita opasnost da Mađarska teško prekrši vrijednosti na kojima se temelji Europska unija (2017/2131(INL), pristup 23.11.2020., dostupno na https://www.europarl.europa.eu/doceo/document/A-8-2018-0250_HR.html.

4. Komunikacija Komisije COM(2019) 163 final, pristup 23.11.2020., dostupno na https://eur-lex.europa.eu/legal-content/HR/TXT/ HTML/?uri=CELEX:52019DC0163\&from=ENhttps://eur-lex.europa.eu/legal-content/ $\mathrm{HR} / \mathrm{TXT} / \mathrm{HTML} /$ ?uri=CELEX:52019DC0163\&from=EN.

5. Komunikacija Komisije COM(2019) 343 final, pristup 23.11.2020., dostupno na https://eur-lex.europa.eu/legal-content/HR/TXT/ HTML/?uri=CELEX:52019DC0343\&from=ENhttps://eur-lex.europa.eu/legal-content/ $\mathrm{HR} / \mathrm{TXT} / \mathrm{HTML} /$ ?uri=CELEX:52019DC0343\&from=EN.

6. Komunikacija Komisije Europskom parlamentu i Vijeću COM(2014) 0158 final, pristup 23.11.2020 dostupno na https://eur-lex.europa.eu/legal-content/HR/TXT/ HTML/?uri=CELEX:52014DC0158\&from=EN.

7. Mišljenje Pravne službe Vijeća 10296/14, pristup 23.11.2020., dostupno na http://data. consilium.europa.eu/doc/document/ST-10296-2014-INIT/hr/pdf.

8. Odgovor Komisije Europskom Parlamentu u vezi Rezolucije od 26. listopada 2016., pristup 23.11.2020., dostupno na https:/oeil.secure.europarl.europa.eu/oeil/popups/ ficheprocedure.do?reference=2015/2254(INL)\&l=en\#tab-0,https://oeil.secure.europarl. europa.eu/oeil/popups/ficheprocedure.do?reference=2015/2254(INL)\&l=en\#tab-0.

9. Prijedlog Uredbe Europskog Parlamenta i Vijeća o zaštiti proračuna unije u slučaju općih nedostataka u pogledu vladavine prava u državama članicama, COM(2018) 324 final, pristup 23.11.2020., dostupno na https://eur-lex.europa.eu/legal-content/HR/TXT/ HTML/?uri=CELEX:52018PC0324\& from=EN.

10. Priopćenje za tisak Parlamenta od 16.1.2020., Pogoršava se stanje vladavine prava $u$ Poljskoj i Mađarskoj, pristup 23.11.2020., dostupno na, https://www.europarl.europa. eu/news/hr/press-room/20200109IPR69907/pogorsava-se-stanje-vladavine-prava-upoljskoj-i-madarskoj.

11. Rezolucija Europskog parlamenta od 10. lipnja 2015. o stanju u Mađarskoj (2015/2700(RSP)). pristup 23.11.2020., dostupno na https://www.europarl.europa.eu/ doceo/document/TA-8-2015-0227_HR.html.

12. Rezolucija Europskog parlamenta od 12. rujna 2018. o prijedlogu kojim se Vijeće poziva da, u skladu s člankom 7. stavkom 1. Ugovora o Europskoj uniji, utvrdi da postoji očita opasnost da Mađarska teško prekrši vrijednosti na kojima se temelji Europska unija (2017/2131(INL)), pristup 23.11.2020., dostupno na https://www.europarl.europa.eu/ doceo/document/TA-8-2018-0340_HR.html.

13. Rezolucija Europskog parlamenta od 14. studenoga 2018. o potrebi za sveobuhvatnim mehanizmom EU-a za zaštitu demokracije, vladavine prava i temeljnih prava (2018/2886(RSP)), pristup 23.11.2020., dostupno na https://www.europarl.europa.eu/ doceo/document/TA-8-2018-0456_HR.html\#def_1_2.

14. Rezolucija Europskog parlamenta od 16. siječnja 2020. o saslušanjima u tijeku u skladu s člankom 7. stavkom 1. UEU-a u pogledu Poljske i Mađarske (2020/2513(RSP)), pristup 23.11.2020., dostupno na https://www.europarl.europa.eu/doceo/document/TA-9-20200014_HR.html.

15. Rezolucija Europskog parlamenta od 25. listopada 2016. s preporukama Komisiji o uspostavi mehanizma EU-a za demokraciju, vladavinu prava i temeljna prava (2015/2254(INL)), pristup 23.11.2020., dostupno na https://www.europarl.europa.eu/ doceo/document/TA-8-2016-0409_HR.html. 
16. Standardni modaliteti saslušanja iz članka 7. stavka 1. UEU-a 10641/2/19, pristup 23.11.2020., dostupno na https://data.consilium.europa.eu/doc/document/ST-106412019-REV-2/hr/pdf.

Sudska praksa

1. Mišljenje nezavisne odvjetnice Sharpston od 26. studenog 2015. u predmetu Vijeće Europske Unije unije protiv Europske komisije, C-660/13, ECLI:EU:C:2015:787.

2. Presuda od 11. srpnja 2019., Europska komisija protiv Republike Italije, C-304/18, ECLI:EU:C:2019:601.

3. Presuda od 14. travnja 2015., Vijeće Europske unije protiv Europske komisije, C-409/13, ECLI:EU:C:2015:217.

4. Presuda od 14. lipnja 2016., Europski parlament protiv Vijeća Europske unije, C-263/14, ECLI:EU:C:2016:435.

5. Presuda od 16. srpnja 2015., Europska komisija protiv Vijeća Europske unije, C-425/13, ECLI:EU:C:2015:483.

6. Predmet Presuda od 2. travnja 2004., Bertelli Gálvez, T-337/03, ECLI:EU:T:2004:106.

7. Presuda od 24. lipnja 2019., Europska komisija protiv Poljske, C-619/18, ECLI:EU:C:2019:531.

8. Presuda od 27. rujna 1988., Grčka protiv Vijeća Europskih Zajednica, C- 204/86, ECLI:EU:C:1988:450.

9. Presuda od 27. veljače 2018., Associação Sindical dos Juizes Portugueses protiv Tribunal de Contas, C-64/16, ECLI:EU:C:2018:117.

10. Presuda od 28. srpnja 2016., Vijeće Europske Unije unije protiv Europske komisije, C-660/13, ECLI:EU:C:2016:616.

11. Presuda od 30. ožujka 1995., Parlament protiv Vijeća Europske unije, C-65/93, ECLI:EU:C:1995:91.

12. Presuda od 6. listopada 2015., Vijeće Europske unije protiv Europske komisije, C-73/14, ECLI:EU:C:2015:663.

13. Presuda od 6. studenog 2012., Komisija protiv Mađarske, C-286/12, ECLI:EU:C:2012:687. 


\section{Stjepan Novak*}

Summary

\section{LOYAL COOPERATION OF THE EUROPEAN UNION INSTITUTIONS IN THE IMPLEMENTATION OF ARTICLE 7 OF THE TREATY OF THE EUROPEAN UNION}

This paper aims to explore do the EU institutions practice mutual sincere cooperation concerning the implementation of article 7 of the TEU, improving its efficiency and the CJEU's capability to improve the efficiency of the aforementioned article indirectly, through protection of the principle of sincere cooperation between institutions. For that purpose, following the introductory part of the paper, an analysis of approaches the EU institutions took in order to try to improve article 7's efficiency and protect values determined in article 2 of the TEU is presented as well as the cooperation the EU institutions realized in the process. In the third part of the paper the author analyses the CJEU case law regarding sincere cooperation between EU institutions and applies conclusions that this case-law provides to exercising institutional cooperation as determined in article 7 of the TEU. In conclusion, this paper shows this cooperation does not satisfy the obligation of sincere cooperation as established in article 13 of the TEU, but that article 7's efficiency can be indirectly improved by CJEU by upholding the obligation of sincere cooperation of EU institutions.

Keywords: article 7. of the TEU; article 13. of the TEU; Union's institution; mutual sincere cooperation; CJEU case law.

\section{Zusammenfassung}

\section{LOYALE ZUSAMMENARBEIT DER EU-INSTITUTIONEN BEI DER IMPLEMENTIERUNG VOM ARTIKEL 7 DES VERTRAGS ZUR EUROPÄISCHEN UNION}

Dieser Beitrag untersucht ob die Zusammenarbeit der EU-Institutionen in Hinsicht auf die Durchführung und Verbesserung von der Wirksamkeit des Art. 7 EUV in Einklang mit dem Grundsatz der loyalen Zusammenarbeit ist, und ob der EU-Gerichtshof, indem er diesen Grundsatz schützt, indirekt auch die Wirksamkeit des Art. 7 EUV bewirken und die Grundwerte aus Art. 2 EUV schützen kann. Dazu

* Stjepan Novak, Ph.D., Ministry of the Interior of the Republic of Croatia; stjepannovak@ hotmail.com. 
wird, nach der Einführung, die Weise auf die EU-Institutionen versucht haben, die Wirksamkeit des Art. 7 EUV zu verbessern analysiert mit Schwerpunkt auf der daraus ergangenen internationalen Zusammenarbeit. Im dritten Teil wird auf die maßgebende Rechtsprechung des EU-Gerichthofs hingewiesen, und die Schlüsse die daraus für die institutionelle Zusammenarbeit aus Art. 7 EUV zu ziehen sind, aufgezeigt. Der Autor schlussfolgert, dass diese Zusammenarbeit nicht der Forderung der loyalen Zusammenarbeit aus dem Art. 13 EUV entspricht, sowie dass der EU-Gerichtshof, indem er diese Forderung stärkt, auch die Wirksamkeit des Art. 7 EUV verbessern kann.

Schlüsselwörter: Art. 7 EUV; Art. 13 EUV; loyale Zusammenarbeit der EUInstitutionen; Rechtsprechung des EU-Gerichtshofs.

Riassunto

\section{LEALE COOPERAZIONE DELLE ISTITUZIONI DELL'UNIONE EUROPEA NELL'APPLICAZIONE DELL'ARTICOLO 7 DEL TRATTATO SULL'UNIONE EUROPEA}

L'obiettivo di questo lavoro è di ricercare se la cooperazione delle istituzioni dell'Unione relativa all'applicazione ed al miglioramento dell'efficienza dell'articolo 7 del TUE sia in conformità con il principio di leale cooperazione e se la Corte di giustizia dell'Unione europea, tutelando il principio di leale cooperazione tra le istituzioni, può indirettamente rafforzare l'efficienza dell'articolo 7 del TUE e proteggere i valori fondamentali contenuti nell'articolo 2 del TUE. A tal fine nel lavoro, dopo l'introduzione, si analizza il modo in cui le istituzioni dell'Unione hanno provato a migliorare l'efficienza dell'articolo 7 del TUE e la cooperazione reciproca che è stata realizzata in tal modo tra loro. Nella terza parte si farà luce sulla giurisprudenza della Corte di giustizia dell'Unione europea riguardo alla questione della leale cooperazione delle istituzioni dell'Unione e si applicheranno le conclusioni provenienti da tale giurisprudenza alla cooperazione istituzionale dell'articolo 7 del TUE. Infine, l'autore conclude che questa cooperazione non corrisponde alla richiesta della leale cooperazione dell'articolo 13 del TUE, ma anche come la Corte di giustizia dell'Unione europea, rafforzando l'obbligo della leale cooperazione delle istituzioni dell'Unione, potrebbe indirettamente migliorare l'efficienza dell'articolo 7 del TUE.

Parole chiave: articolo 7 TUE; articolo 13 TUE; leale cooperazione delle istituzioni dell'Unione; giurisprudenza della Corte di giustizia dell'Unione europea. 